\title{
um \\ Challenges in Ramularia collo-cygni Control
}

\author{
Andres Mäe *(D) and Riinu Kiiker (D)
}

check for

updates

Citation: Mäe, A.; Kiiker, R.

Challenges in Ramularia collo-cygni

Control. Encyclopedia 2022, 2, 256-263.

https://doi.org/10.3390/

encyclopedia2010017

Academic Editor: Łukasz Stępień

Received: 13 October 2021

Accepted: 25 January 2022

Published: 27 January 2022

Publisher's Note: MDPI stays neutral with regard to jurisdictional claims in published maps and institutional affiliations.

Copyright: (c) 2022 by the authors. Licensee MDPI, Basel, Switzerland. This article is an open access article distributed under the terms and conditions of the Creative Commons Attribution (CC BY) license (https:// creativecommons.org/licenses/by/ $4.0 /)$.

\begin{abstract}
Department of Plant Protection, Estonian Crop Research Institute, 48309 Jõgeva, Estonia; riinu.kiiker@etki.ee * Correspondence: andres.mae@etki.ee
\end{abstract}

Definition: Ramularia leaf spot (RLS), caused by the fungus Ramularia collo-cygni, has recently become widespread in Europe. Succinate dehydrogenase inhibitor (SDHI) and demethylation inhibitor (DMI) fungicides are mainly applied for disease control on barley fields, but pathogen isolates with a reduced sensitivity can cause difficulties. There is an urgent need for new spring barley cultivars that are more resistant to RLS development and can inhibit $R$. collo-cygni epidemics.

Keywords: Ramularia leaf spot; fungicide target proteins; CYP51; azoles; SDHI; mlo gene

\section{Introduction}

Barley (Hordeum vulgare L.) is one of the most important cereal crops grown in temperate regions worldwide [1]. Among the various pests and diseases that threaten sustainable barley cultivation [2], Ramularia leaf spot (RLS) — caused by an ascomycete, Ramularia collocygni-has become a new threat to barley cultivation. The first reported case of the disease dates back to 1893 in northern Italy and was identified by a notable botanist, Fridiano Cavara. For a century, RLS was a minor disease and did not cause any serious problems in barley cultivation, but the majority of $R$. collo-cygni outbreaks have been reported in the last few decades. The first official records in Germany, the UK, Ireland, and New Zealand are from the 1990s. In Finland, Sweden, Denmark, and France, the first records are from the 2000s, and in Estonia, Spain, and Australia, the first records are after 2010 [3]. Since the beginning of 2000, RLS has been considered to be an emerging disease of barley in Europe, South America, and New Zealand [2,4,5]. It is possible that RLS can lead to moderate barley yield losses of $5-20 \%$ or greater. Although the trigger of these increasing RLS epidemics is still under debate, $R$. collo-cygni adaptation to widely distributed RLS-susceptible barley cultivars and fungicides along with heat stress under global climate change will lead to a risk of future RLS epidemics $[3,6]$.

\section{Epidemiology of Ramularia collo-cygni}

It has been speculated that the seed-borne stage in the life cycle of $R$. collo-cygni is the most common means of the pathogen's worldwide distribution [7]. In the infected seed, the pathogen hides in the lemma, pericarp, and embryo [7]. The global trade of barley seeds might be one of the main reasons this pathogen has spread worldwide. The control of the pathogen by chemical seed treatment has been examined but, to date, without success [8]. In addition to barley seeds, volunteers, crop debris, and other grasses may contribute to the pathogen's survival and local sources of inoculum [9].

Air-borne asexual spores and sexual ascospores of R. collo-cygni disperse during the growing season and infect susceptible hosts [10,11]. The pathogen infects the seeds during plant growth, and with no external inoculum, it colonizes the emerging leaf layers [11]. The endophytic phase of R. collo-cygni without any visual disease symptoms continues until it undergoes developmental changes transforming it into a detrimental necrotrophic pathogen; these changes may be triggered by numerous factors (e.g., a nutrient deficiency, changes in the levels of reactive oxygen species in host tissues, and plant 
senescence) $[9,12,13]$. Furthermore, the production of several virulence factors by $R$. collocygni during leaf infection is probably involved in the development of the symptoms of RLS disease [14]. The visual symptoms of RLS often develop in diseased plants after ear emergence, although, in conducive environmental conditions, symptoms can be detected even sooner $[5,15]$.

It is still poorly understood why $R$. collo-cygni became an aggressive pathogen in most European countries at the beginning of the 2000s. Many factors, as well as the lack of RLS-resistant cultivars, reduced fungicide efficacy, and climate change, could have affected the disease's occurrence and development. Barley breeding has concentrated on introducing genes conferring resistance to intensive powdery mildew attacks into new cultivars; today, cultivars carrying the mlo-11 mutation are widely used to provide plants with durable resistance to powdery mildew infections (as reviewed by Brown and Rant [16]). Unfortunately, mlo-11-mutation cultivars are more susceptible to several non-biotrophic diseases including RLS [17]. The plant's genetic resistance to RLS remains unknown. In addition, as a consequence of the intensive use of fungicides in the past, several fungicides have reduced efficacy in barley disease control, and the crop is therefore unprotected against $R$. collo-cygni attack. The exposure to fungicides may have led to an imbalanced soil and plant-related microbial community as well as a reduction in microorganisms antagonistic to $R$. collo-cygni.

In the Baltic countries, RLS was first diagnosed in Lithuania in 2004 [18]. In 2012, the first few attacks of RLS were only identified in Jõgeva county near the Estonian Crop Research Institute [19]. Field monitoring from 2015 to 2020 showed that R. collo-cygni had rapidly spread to the majority of barley-cropping areas (Figure 1). Due to the increasing spread of R. collo-cygni, RLS has become a newly emerging disease in Estonian barley fields. The control strategies for barley protection mainly rely on DMI- and SDHI-class fungicides-for instance, commercial pesticide products such as Input (Bayer AG, Leverkusen, Germany; a.i. prothioconazole $160 \mathrm{~g} / \mathrm{L}$, spiroxamine $300 \mathrm{~g} / \mathrm{L}$ ), Tango Super (BASF, Ludwigshafen, Germany; a.i. epoxiconazole $84 \mathrm{~g} / \mathrm{L}$, fenpropimorph $250 \mathrm{~g} / \mathrm{L}$ ), Viverda (BASF, Ludwigshafen, Germany; a.i. boscalid 140 g/L, pyraclostrobin 60 g/L, epoxiconazole $50 \mathrm{~g} / \mathrm{L}$ ), and Priaxor (BASF, Ludwigshafen, Germany; a.i. fluxapyroxad $75 \mathrm{~g} / \mathrm{L}$, pyraclostrobin $150 \mathrm{~g} / \mathrm{L}$ ). This has led to the accumulation of resistance mutations in the target proteins' genes and increased the fungicide-resistant population [20]. We also cannot exclude the fact that several popular barley cultivars (e.g., 'Soldo', 'Montoya', 'Katniss', and 'KWS Irina') grown in Estonia carry the mlo-11 mutation in the genome. Consequently, similar factors have favored the spread of $R$. collo-cygni in Estonia as well as in other European countries.

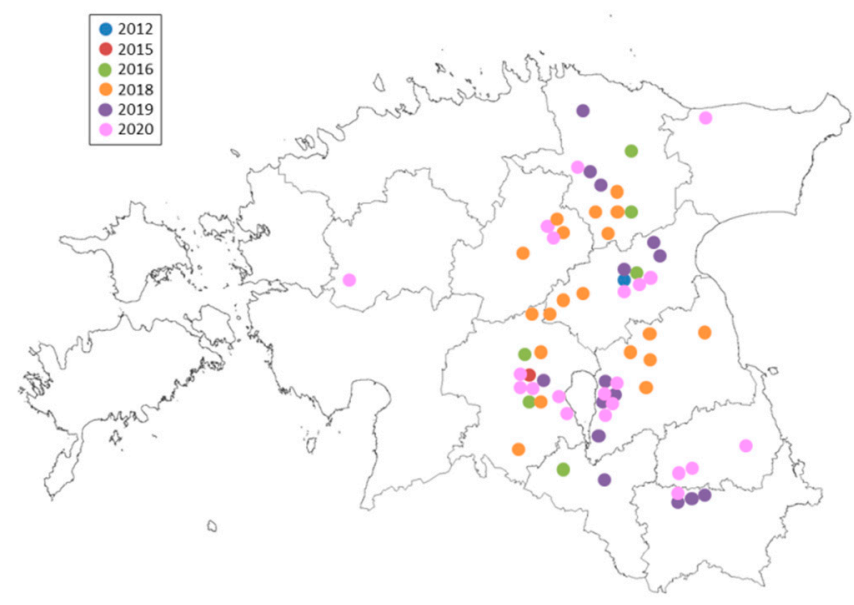

Figure 1. Ramularia collo-cygni spread and detection in 2012-2020 in Estonia.

R. collo-cygni populations across Europe frequently recombine and are highly diverse, which enables them to be adaptive to different environmental conditions [21,22]. Genetic 
studies have shown highly admixed $R$. collo-cygni populations without geographical clustering, which emphasizes the significance of the global seed market and delivery in spreading the pathogen genotypes and accelerating the spread of fungicide resistance [22]. It is challenging to assume the presence and spread of the pathogen because, in the endophytic phase, RLS symptoms are not present. Typical symptoms occur in the late growing season and often lead to the mistaken diagnosis of other diseases and physiological leaf spots [23].

\section{Fungicide Resistance in R. collo-cygni Populations}

Fungicides are commonly used in crop protection for yield benefits in Europe, especially in countries such as Great Britain and Ireland with high humidity favorable for pathogen epidemics in the growing season [24]. R. collo-cygni presents a substantial risk of acquiring resistance to fungicides applied to barley fields [25]. R. collo-cygni in several European countries (e.g., the UK, France, Denmark, and Estonia) has already developed resistance to quinone-outside inhibitors (QoIs; FRAC Code 11), a single-site-inhibiting fungicide class that previously showed high efficacy $[20,26,27]$. Recently, disease control has been accomplished using two single-site fungicide classes, the succinate dehydrogenase inhibitors (SDHIs; FRAC Code 7) and the demethylation inhibitors (DMIs; FRAC Code 3), as well as the multi-site inhibitor chlorothalonil (FRAC Code M 05) [4]. Despite the high efficacy of chlorothalonil in RLS control [28], chlorothalonil-based fungicides were forbidden by the European Food Safety Association (EFSA) from 2020 onwards because of serious environmental safety concerns and a high risk to amphibians and fish [29]. The European regulation 128/2009 managing the use of pesticides has recently withdrawn various fungicides from the market because of environmental and health-related concerns. These changes will inevitably lead to adjustments in future resistance-breeding strategies to produce an increased number of abiotic- and biotic-stress-tolerant barley cultivars and focus on effective integrated pest-management strategies.

\subsection{Status of DMI-Fungicide Sensitivity}

DMIs have been beneficial for maintaining the health of crops and achieving higher yields from the fields. However, the wide use of DMIs for more than three decades has led to the emergence of adapted strains of cereal pathogens and a reduction in the efficacy of the active ingredients of fungicides $[24,30,31]$. The most relevant mechanism for DMIresistant adaptations in numerous fungal pathogens is mutations in the coding region of CYP51 [32,33]. In total, 12 different alterations and 15 different $R$. collo-cygni CYP51 haplotypes were identified based on the mutation combinations in 2017 in Europe [34]. The most frequent haplotype was C1, with the mutations I381T, I384L, and Y459C in CYP51, and the second-most-common haplotype, C3, had a combination of I381T, I384L, and $\mathrm{Y} 461 \mathrm{H}$ mutations [34]. These haplotypes are spreading, which results in a lower field efficacy for DMI fungicides [34]. In eastern Europe-for instance, Estonia - the development of fungicide resistance has been slower [20]. However, two mutations-I381T and I384Twere simultaneously present in the same R. collo-cygni isolates in $93-96 \%$ of the isolates, and mutation combinations similar to haplotype $C 1$ occurred in $70-80 \%$ of the isolates recently collected in Estonia [20]. Unfortunately, the CYP51 gene's evolution and additional resistance mechanisms (e.g., the combination of gene mutations with promoter insertions or an enhanced efflux) in R. collo-cygni are yet unknown.

We observed a significant shift and wider distribution in the $\mathrm{EC}_{50}$ values of epoxiconazole (EPX), prothioconazole-desthio (PTZ-D), and mefentrifluconazole (MEF) in 2020 compared with 2019 in the Estonian R. collo-cygni population, as illustrated in Figure 2 [20]. In the Estonian R. collo-cygni population, a remarkable number of isolates had higher $\mathrm{EC}_{50}$ values (>1.0 ppm) for EPX and PTZ-D in 2020 compared with 2019 [20]. The selection pressure for DMI-class fungicides in Estonia was lower than that in Western Europe, and fungicide resistance has developed more slowly in the pathogen population. The climatic conditions in Estonia are also less favorable for RLS, and chemical control is, therefore, less intensively used. In countries with more severe or numerous RLS epidemics (e.g., the UK, 
Germany, and Austria), the chemical control of the disease is a common practice and, since 2015, R. collo-cygni populations have significantly lost sensitivity to DMI fungicides [35].
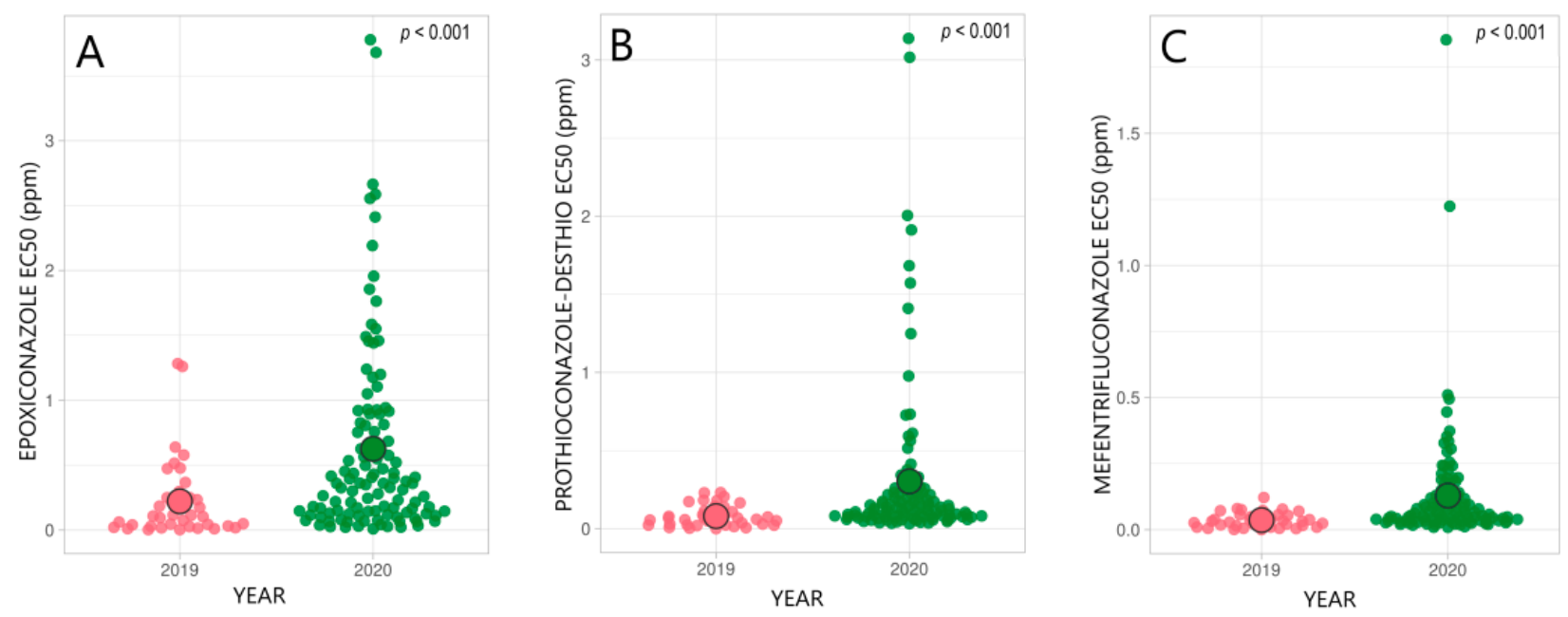

Figure 2. Distribution of the azole sensitivity of the R. collo-cygni population in 2019 and 2020 in Estonia. Epoxiconazole (A); prothioconazole-desthio (B), and mefentrifluconazole (C) were tested. $\bigcirc$ indicates the average $\mathrm{EC}_{50}$ value (ppm) in a population; $p<0.001$ shows a significant difference between the years [20].

Several research groups have shown that DMI fungicides, e.g., MEF and tebuconazole (TEB), encounter cross-resistance in the wheat pathogen Zymoseptoria tritici population; farmers should be careful with extensive applications of TEB for cereal-plant protection [36,37]. A high positive correlation between PTZ-D and MEF sensitivity was noticed in the R. collo-cygni population [20]. EPX sensitivity was significantly correlated with PTZ-D and MEF sensitivity [20].

\subsection{Status of SDHI-Fungicide Sensitivity}

SDHI fungicides have been highly efficient, and the emergence of resistance to SDHIs in the field has been rare. Several mutations in the SdhB (B-H266Y/R, B-T267I, and B-I268V) and SdhC subunits (C-N87S, C-H146R, and C-H153R) of the SDH enzyme in R. collo-cygni can be observed [34]. The future of SDHIs' field performance could be threatened as various studies have shown that laboratory mutants, as well as SDHI-insensitive isolates in Europe, have increased since 2014 [34,38]. Increased resistance to SDHIs in other widespread cereal pathogens, Pyrenophora teres [39] and Z. tritici [40,41], highlights the negative outcomes and high risk of SDHI-resistance evolution.

Recently, the mutations C-H146R and C-H153R in the SdhC subunit, which confer a noticeable reduction in SDHI sensitivity, and C-N87S, which reduces sensitivity, were identified in R. collo-cygni isolates collected from Germany, France, Austria, UK, and Ireland from 2014 to $2017[34,35]$. Although during the last decade SDHI-class fungicides have often been applied for crop protection in Estonia, mutations have only occurred in the SdhC subunit [20]. The prevailing mutation C-H146R in the SdhC subunit, which significantly increases the resistance factor, was detected in $55-63 \%$ of the $R$. collo-cygni isolates in recent years in Estonia [20]. Figure 3 illustrates the distribution of the SDHI-fungicide sensitivity of Estonian R. collo-cygni in 2019 and 2020, with highly variable EC $_{50}$ values ranging from 0 to $5 \mathrm{ppm}$, as determined in a microtiter plate assay [20]. 

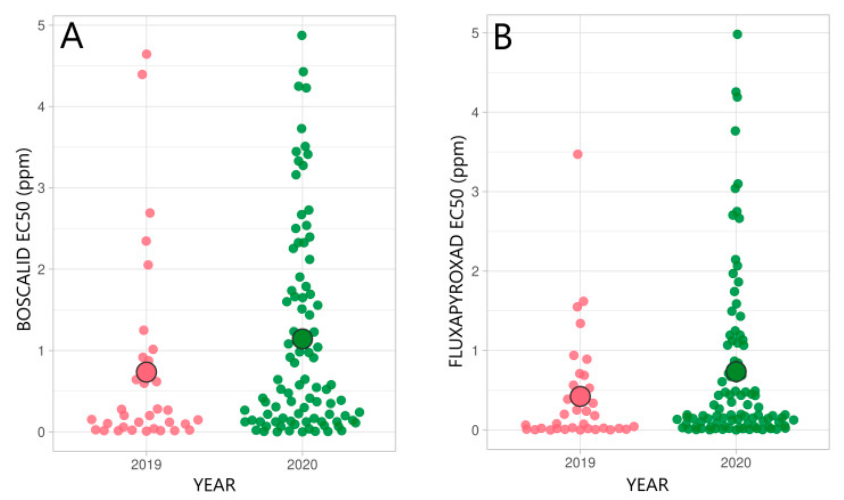

Figure 3. Distributions of the SDHI-fungicide sensitivity of R. collo-cygni to boscalid (A) and fluxapyroxad (B) in 2019 and 2020 in Estonia. $\bigcirc$ shows the average $E_{50}$ value (ppm) in a population [20].

\section{Common Barley Cultivars Enhance RLS Epidemics}

One possibility for reducing the fungicide input in plant protection is to breed and cultivate sustainable barley cultivars with multiple sources of host-plant resistance. Breeding new cultivars with greater disease resistance has had a significant impact on the epidemiology of plant diseases. None of the current common cultivars have full resistance to RLS.

The mlo gene in the barley genome is agronomically highly significant because it is involved in the development of barley's resistance to the powdery mildew pathogen Blumeria graminis f. sp. hordei [42]. The powdery-mildew-resistance gene, mlo-11, was identified in 1942 in an Ethiopian barley line, Grannenlose Zweizeilige. All the known mlo alleles are non-functional [43]. However, conventional plant breeding is time-consuming and the first powdery-mildew-resistant cultivar with the mlo-11 allele was ready for cultivation in 1979 [44]. After the release of the barley cultivar Atem, the interest in the mlo cultivars rapidly increased and the success of cultivars with the mlo mutant allele has continued. Around $70 \%$ of the European spring barley cultivars have the mlo mutant allele in the genome [45].

\section{Pleiotropic Effect of mlo Alleles on RLS}

Unfortunately, the mutant $m l o$ alleles introduced into barley cultivars can have deleterious agronomic effects, including a reduced yield [46] and a higher susceptibility to facultative pathogens including R. collo-cygni [17]. The development of RLS as an emerging new disease of spring barley in many regions may be influenced by the widespread use of mlo alleles (particularly mlo-11) in plant breeding and the exploitation of these cultivars. RLS symptoms typically appear as the crop senesces, with a reduction in the activity of the host's antioxidant system, implying that the progress of RLS may be connected to host stress $[13,47]$. The effect of $m l o$ alleles on RLS may be related to a complex rearrangement of the physiological processes in leaves, the ROS levels, or both, according to the research of Oxley and Havis [48]. Genes that regulate cell death in barley (e.g., nec and ror) interact with the negative cell-death regulator MLO, which affects plant-disease development and pathogens (such as R. collo-cygni) $[17,49,50]$. Rapid leaf senescence in mlo cultivars may induce a faster transformation of R. collo-cygni from an endophytic to a necrotrophic lifestyle, which could be increased further by external factors that promote oxidative stress in the plant [51,52]. Drought-tolerant transgenic barley plants that overexpressed stressed-related NAC1 (SNAC1) had delayed senescence and showed greater resilience to abiotic stressors and RLS infection [51]. If abiotic-stress factors induce fungal development from an endophyte to a necrotrophic pathogen, then plants with a greater tolerance to abiotic stress also have greater protection against disease development.

\section{Future Challenges}

Under the current climate change trajectory, RLS epidemics are predicted to increase [5]. For sustainability and high yields in barley production, the crop needs to be protected as 
effectively as possible according to the best scientific knowledge and experimental data. Therefore, fungicides to which the pathogen is sensitive are preferable for use in diseasecontrol strategies. Combining and rotating fungicides with different modes of action may also help. A high dose may be required under an elevated disease pressure, particularly for susceptible cultivars or where the sensitivity has been reduced and the dose has to be increased to maintain effective control. Unfortunately, in most cases, high fungicide doses accelerate the development of fungicide resistance in the pathogen population [53].

Barley is an important food and feed crop around the world, and the cultivars grown should be able to adapt to different growing conditions and geographical areas. Under increasing RLS pressure, the mechanisms of RLS infection and the pathogen's epidemiology require further research, and barley cultivars need to be less adversely affected by plant pathogens. To combat the challenges of future food security, plant-breeding strategies and methods should be innovative and rapid. As the plant-defense mechanisms providing crossresistance to different fungal pathogens are still not understood in detail, the widespread use of a few single resistance alleles in plant breeding will not necessarily be beneficial. This practice may have contrasting effects on the plant-disease epidemiology, decreasing the fitness of one pathogen and increasing that of another.

Author Contributions: Conceptualization, A.M. and R.K.; writing-original draft preparation, A.M. and R.K.; writing-review and editing, A.M. and R.K.; funding acquisition, A.M. All authors have read and agreed to the published version of the manuscript.

Funding: This study received funding from the Ministry of Rural Affairs of the Republic of Estonia with project no. 10.1-2/177 and from the Ministry of Education and Research of the Republic of Estonia with project "Sordiaretus" no. 2014-2020.4.01.16-0037.

Conflicts of Interest: The authors declare no conflict of interest.

Entry Link on the Encyclopedia Platform: https:/ / encyclopedia.pub/20287.

\section{References}

1. Newton, A.C.; Flavell, A.J.; George, T.; Leat, P.; Mullholland, B.; Ramsay, L.; Revoredo-Giha, C.; Russell, J.; Steffenson, B.J.; Swanston, J.S.; et al. Crops that feed the world 4. Barley: A resilient crop? Strengths and weaknesses in the context of food security. Food Secur. 2011, 3, 141-178. [CrossRef]

2. Walters, D.R.; Havis, N.D.; Oxley, S.J. Ramularia collo-cygni: The biology of an emerging pathogen of barley. FEMS Microbiol. Lett. 2008, 279, 1-7. [CrossRef] [PubMed]

3. Dussart, F.; Creissen, H.E.; Havis, N.D. Ramularia collo-cygni-An Enemy in Waiting. In eLS; 2020; pp. 1-8. Available online: https: //pure.sruc.ac.uk/en/publications/riamularia-collo-cygnii-an-enemy-in-waiting (accessed on 13 October 2021). [CrossRef]

4. Havis, N.; Brown, J.K.M.; Clemente, G.; Frei, P.; Jedryczka, M.; Kaczmarek, J.; Kaczmarek, M.; Matusinsky, P.; McGrann, G.; Pereyra, S.; et al. Ramularia collo-cygni-An Emerging Pathogen of Barley Crops. Phytopathology 2015, 105, 895-904. [CrossRef] [PubMed]

5. McGrann, G.D.; Havis, N. Ramularia Leaf Spot: A Newly Important Threat to Barley Production. Outlooks Pest Manag. 2017, 28, 65-69. [CrossRef]

6. West, J.S.; Townsend, J.A.; Stevens, M.; Fitt, B.D.L. Comparative biology of different plant pathogens to estimate effects of climate change on crop diseases in Europe. Eur. J. Plant Pathol. 2012, 133, 315-331. [CrossRef]

7. Matusinsky, P.; Leisova-Svobodova, L.; Gubis, J.; Hudcovicova, M.; Klcova, L.; Gubisova, M.; Marik, P.; Tvaruzek, L.; Minarikova, V. Impact of the seed-borne stage of Ramularia collo-cygni in barley seed. J. Plant Pathol. 2011, 93, 679-689. [CrossRef]

8. Havis, N.D.; Oxley, S.J.P. Investigation the life cycle of Ramularia collo-cygni using PCR diagnostics. In First European Ramularia Workshop 12-14 March 2006; Koopmann, B., Oxley, S., Schützendübel, A., von Tiedemann, A., Eds.; Georg-August-Universität: Göttingen, Germany, 2006; pp. 39-44.

9. Kaczmarek, M.; Piotrowska, M.; Fountaine, J.; Gorniak, K.; McGrann, G.; Armstrong, A.; Wright, K.; Newton, A.; Havis, N. Infection strategy of Ramularia collo-cygni and development of Ramularia leaf spot on barley and alternative graminaceous hosts. Plant Pathol. 2016, 66, 45-55. [CrossRef]

10. Stabentheiner, E.; Minihofer, T.; Huss, H. Infection of Barley by Ramularia collo-cygni: Scanning Electron Microscopic Investigations. Mycopathologia 2009, 168, 135-143. [CrossRef]

11. Havis, N.D.; Nyman, M.; Oxley, S.J.P. Evidence for seed transmission and symptomless growth of R amularia collo-cygni in barley (H ordeum vulgare). Plant Pathol. 2013, 63, 929-936. [CrossRef]

12. Rodriguez, R.; Redman, R. More than 400 million years of evolution and some plants still can't make it on their own: Plant stress tolerance via fungal symbiosis. J. Exp. Bot. 2008, 59, 1109-1114. [CrossRef] 
13. Schützendübel, A.; Stadler, M.; Wallner, D.; von Tiedemann, A. A hypothesis on physiological alterations during plant ontogenesis governing susceptibility of winter barley to Ramularia leaf spot. Plant Pathol. 2008, 57, 518-526. [CrossRef]

14. Harvey, I. Epidemiology and control of leaf and awn spot of barley caused by Ramularia collocygni. N. Z. Plant Prot. 2002, 55, 331-335. [CrossRef]

15. Sjökvist, E.; Lemcke, R.; Kamble, M.; Turner, F.; Blaxter, M.; Havis, N.; Lyngkjær, M.; Radutoiu, S. Dissection of Ramularia Leaf Spot Disease by Integrated Analysis of Barley and Ramularia collo-cygni Transcriptome Responses. Mol. Plant-Microbe Interact. 2019, 32, 176-193. [CrossRef] [PubMed]

16. Brown, J.K.M.; Rant, J.C. Fitness costs and trade-offs of disease resistance and their consequences for breeding arable crops. Plant Pathol. 2013, 62, 83-95. [CrossRef]

17. McGrann, G.; Stavrinides, A.; Russell, J.; Corbitt, M.M.; Booth, A.; Chartrain, L.; Thomas, W.T.B.; Brown, J.K.M. A trade off between mlo resistance to powdery mildew and increased susceptibility of barley to a newly important disease, Ramularia leaf spot. J. Exp. Bot. 2014, 65, 1025-1037. [CrossRef]

18. Leistrumaite, A.; Liatukas, Ž. Resistance of spring barley cultivars to the new disease Ramularia leaf spot, caused by Ramularia collo-cygni. Agron. Res. 2006, 4, 251-255.

19. Sooväli, P.; Tikhonova, M.; Matušinsky, P. First Report of Ramularia Leaf Spot Caused by Ramularia collo-cygni on Leaves and Seeds of Barley in Estonia. Plant Dis. 2014, 98, 997. [CrossRef]

20. Kiiker, R.; Juurik, M.; Mäe, A. Fungicide Resistance Evolving in Ramularia collo-cygni Population in Estonia. Microorganisms 2021, 9, 1514. [CrossRef]

21. Leisova-Svobodova, L.; Matusinsky, P.; Kucera, L. Variability of the Ramularia collo-cygni Population in Central Europe. J. Phytopathol. 2012, 160, 701-709. [CrossRef]

22. Piotrowska, M.; Ennos, R.; Fountaine, J.; Burnett, F.; Kaczmarek, M.; Hoebe, P. Development and use of microsatellite markers to study diversity, reproduction and population genetic structure of the cereal pathogen Ramularia collo-cygni. Fungal Genet. Biol. 2016, 87, 64-71. [CrossRef]

23. Strobel, D.; Bryson, R.; Stammler, G.; Prochnow, J. A European overview of the occurrence of Ramularia collo-cygni and its sensitivity to fluxapyroxad. In Proceedings of the 11th Conference of the European Foundation for Plant Pathology-Healthy People, Krakow, Poland, 8-13 September 2014.

24. Jørgensen, L.N.; Heick, T.M. Azole Use in Agriculture, Horticulture, and Wood Preservation-Is It Indispensable? Front. Cell. Infect. Microbiol. 2021, 11, 806. [CrossRef] [PubMed]

25. Stam, R.; Sghyer, H.; Tellier, A.; Hess, M.; Hückelhoven, R. The Current Epidemic of the Barley Pathogen Ramularia collo-cygni Derives from a Population Expansion and Shows Global Admixture. Phytopathology 2019, 109, 2161-2168. [CrossRef] [PubMed]

26. Kuck, K.-H.; Russell, P.E. FRAC: Combined resistance risk assessment. Asp. Appl. Biol. 2006, 78, 3-10.

27. Fountaine, J.M.; Fraaije, B.A. Development of QoI resistant alleles in populations of Ramularia collo-cygni. In Proceedings of the Aspects of Applied Biology 92, The 2nd European Ramularia Workshop-A New Disease and Challenge in Barley Production; Association of Applied Biologists, The Warwick Enterprise Park Wellesbourne: Warwick/Edinburgh, UK, 2009; pp. $123-126$.

28. Matusinsky, P.; Svobodova-Leisova, L.; Mariks, P.; Tvaruzek, L.; Stemberkova, L.; Hanusova, M.; Minarikova, V.; Vysohlidova, M.; Spitzer, T. Frequency of a mutant allele of cytochrome b conferring resistance to Ool fungicides in the Czech population of Ramularia collo-cygni. J. Plant Dis. Prot. 2010, 117, 248-252. [CrossRef]

29. Havis, N.D.; Gorniak, K.; Taylor, J.; Stanisz-Migal, M.; Burnett, F.J. Controlling Ramularia leaf spot in barley crops. In Proceedings of the Proceedings Crop Production in Northern Britain 2018, Dundee, UK, 27-28 February 2018; The Association for Crop Protection in Northern Britain: Dundee, UK, 2018; pp. 91-96.

30. Dooley, H.; Shaw, M.W.; Spink, J.; Kildea, S. The effect of succinate dehydrogenase inhibitor/azole mixtures on selection of Zymoseptoria triticiisolates with reduced sensitivity. Pest Manag. Sci. 2015, 72, 1150-1159. [CrossRef]

31. Clark, W.S. Septoria tritici and azole performance. Asp. Appl. Biol. 2006, 78, 127-132.

32. Lucas, J.A.; Hawkins, N.J.; Fraaije, B.A. The Evolution of Fungicide Resistance. In Advances in Applied Microbiology; Elsevier Ltd.: Amsterdam, The Netherlands, 2015; Volume 90, pp. 29-92.

33. Huf, A.; Rehfus, A.; Lorenz, K.H.; Bryson, R.; Voegele, R.T.; Stammler, G. Proposal for a new nomenclature for CYP51haplotypes inZymoseptoria triticiand analysis of their distribution in Europe. Plant Pathol. 2018, 67, 1706-1712. [CrossRef]

34. Rehfus, A.; Matusinsky, P.; Strobel, D.; Bryson, R.; Stammler, G. Mutations in target genes of succinate dehydrogenase inhibitors and demethylation inhibitors in Ramularia collo-cygni in Europe. J. Plant Dis. Prot. 2019, 126, 447-459. [CrossRef]

35. FRAC-Fungicide Resistance Action Committee. Available online: http:/ / www.frac.info/ (accessed on 6 June 2019 ).

36. Heick, T.M.; Matzen, N.; Jørgensen, L.N. Reduced field efficacy and sensitivity of demethylation inhibitors in the Danish and Swedish Zymoseptoria tritici populations. Eur. J. Plant Pathol. 2020, 157, 625-636. [CrossRef]

37. Kiiker, R.; Juurik, M.; Heick, T.; Mäe, A. Changes in DMI, SDHI, and QoI Fungicide Sensitivity in the Estonian Zymoseptoria tritici Population between 2019 and 2020. Microorganisms 2021, 9, 814. [CrossRef]

38. Piotrowska, M.J.; Fountaine, J.M.; Ennos, R.A.; Kaczmarek, M.; Burnett, F. Characterisation of Ramularia collo-cygni laboratory mutants resistant to succinate dehydrogenase inhibitors. Pest Manag. Sci. 2016, 73, 1187-1196. [CrossRef]

39. Rehfus, A.; Miessner, S.; Achenbach, J.; Strobel, D.; Bryson, R.; Stammler, G. Emergence of succinate dehydrogenase inhibitor resistance of Pyrenophora teres in Europe. Pest Manag. Sci. 2016, 72, 1977-1988. [CrossRef] [PubMed] 
40. Dooley, H.; Shaw, M.W.; Mehenni-Ciz, J.; Spink, J.; Kildea, S. Detection of Zymoseptoria tritici SDHI-insensitive field isolates carrying the SdhC -H152R and SdhD -R47W substitutions. Pest Manag. Sci. 2016, 72, 2203-2207. [CrossRef]

41. Rehfus, A.; Strobel, D.; Bryson, R.; Stammler, G. Mutations in sdh genes in field isolates of Zymoseptoria tritici and impact on the sensitivity to various succinate dehydrogenase inhibitors. Plant Pathol. 2017, 67, 175-180. [CrossRef]

42. Büschges, R.; Hollricher, K.; Panstruga, R.; Simons, G.; Wolter, M.; Frijters, A.; van Daelen, R.; van der Lee, T.; Diergaarde, P.; Groenendijk, J.; et al. The Barley Mlo Gene: A Novel Control Element of Plant Pathogen Resistance. Cell 1997, 88, 695-705. [CrossRef]

43. Jørgensen, I.H. Discovery, characterization and exploitation of Mlo powdery mildew resistance in barley. Euphytica 1992, 63, 141-152. [CrossRef]

44. Lyngkjær, M.; Newton, A.C.; Atzema, J.L.; Baker, S.J. The Barley mlo-gene: An important powdery mildew resistance source. Agronomie 2000, 20, 745-756. [CrossRef]

45. Dreiseitl, A. Specific Resistance of Barley to Powdery Mildew, Its Use and Beyond. A Concise Critical Review. Genes 2020, 11, 971. [CrossRef]

46. Kjær, B.; Jensen, H.P.; Jensen, J.; Jørgensen, J.H. Associations between three ml-o powdery mildew resistance genes and agronomic traits in barley. Euphytica 1990, 46, 185-193. [CrossRef]

47. McGrann, G.R.D.; Burt, C.; Nicholson, P.; Brown, J.K.M. Differential effects of lesion mimic mutants in barley on disease development by facultative pathogens. J. Exp. Bot. 2015, 66, 3417-3428. [CrossRef]

48. Oxley, S.J.P.; Havis, N.D. Development of Ramularia collo-cygni on spring barley and its impact on yield. In Proceedings of the Dundee Conference: Crop protection in Northern Britain 2004, Dundee, UK, 24-25 February 2004; Heilbronn, T., Ed.; pp. 147-152.

49. Rostoks, N.; Schmierer, D.; Mudie, S.; Drader, T.; Brueggeman, R.; Caldwell, D.G.; Waugh, R.; Kleinhofs, A. Barley necrotic locus nec1 encodes the cyclic nucleotide-gated ion channel 4 homologous to the Arabidopsis HLM1. Mol. Genet. Genom. 2005, 275, 159-168. [CrossRef] [PubMed]

50. McGrann, G.R.D.; Brown, J.K.M. The role of reactive oxygen in the development of Ramularia leaf spot disease in barley seedlings. Ann. Bot. 2017, 121, 415-430. [CrossRef] [PubMed]

51. McGrann, G.R.D.; Miller, S.; Havis, N. The enhanced magnaporthe resistance 1 locus affects Ramularia leaf spot development in barley. Eur. J. Plant Pathol. 2019, 156, 123-132. [CrossRef]

52. McGrann, G.R.D.; Steed, A.; Burt, C.; Goddard, R.; Lachaux, C.; Bansal, A.; Corbitt, M.; Gorniak, K.; Nicholson, P.; Brown, J.K.M. Contribution of the drought tolerance-related Stress-responsive NAC 1 transcription factor to resistance of barley to R amularia leaf spot. Mol. Plant Pathol. 2014, 16, 201-209. [CrossRef] [PubMed]

53. Bosch, F.V.D.; Paveley, N.; Shaw, M.; Hobbelen, P.; Oliver, R.A. The dose rate debate: Does the risk of fungicide resistance increase or decrease with dose? Plant Pathol. 2011, 60, 597-606. [CrossRef] 